\title{
A Study on Modelling Methodology of Oligopolistic Virtual Market and its Application into Resource Allocation Problem
}

\author{
Toshiya Kaihara Member (Kobe Univeristy, kaihara@cs.kobe-u.ac.jp) \\ Susumu Fujii Non-member (Kobe Univeristy, fuji@@cs.kobe-u.ac.jp)
}

Keywords: manufacturing system, multi-agent, oligopolic virtual market, equilibrium solution, resource allocation problem

\section{Introduction}

Recently, manufacturing systems have become large scale and complex. Social scientific approach is one of the promising methods to facilitate effective operation for the resource allocation problems in manufacturing systems, since the approach takes an analogy of social systems with optimality and robustness in nature. In this paper, we clarify the several important characteristics of the oligopolistic virtual market by computer simulation experiments, and try to apply the proposed method into a utility computing operational problem to validate its effectiveness into resource allocation problems.

\section{Oligopolic Virtual Market}

There exists a market-oriented programming to construct a computational market (i.e. virtual market), which consists of several heterogeneous agents. Agent activities in terms of products required and supplied are defined so as to reduce an agent's decision problem to evaluate the tradeoffs of acquiring different products in the market-oriented programming. These tradeoffs are represented in terms of market prices, which define common scale of value across the various products. The problem for designers of computational markets is to specify the mechanism by which agent interactions determine prices.

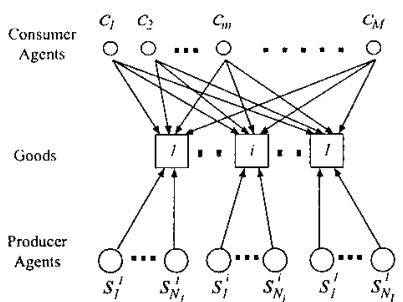

Fig. 1. Oligopolic virtual market model

Utilities of the agents, which consists of the virtual market, are described into trading fuctions, such as demand function and supply function. In this oligopolic virtual market, the demand function of consumer agents $\left(c_{m}\right)$ about goods $i$ are defined as following equations:

$$
x_{i}^{c_{m}}(p)=\frac{b_{i}^{c_{m}} B^{c_{m}}}{p_{i}}(i=1,2, \ldots, I) .
$$

where $x_{i}^{c_{m}}$ : demand at price $p_{i}, B^{c_{m}}$ : budget, $a_{i}^{s_{n}}, b_{i}^{c_{m}}$ : constant values

Then, the supply amount $\left(y^{s_{n}^{i}}\right)$ of supply agent $\left(s_{n}\right)$ for goods $i$ are calculated as a solution of following equations:

$$
P\left(y^{s_{n}^{i}}\right)+\frac{\partial P\left(y^{s_{n}^{i}}\right)}{\partial y^{s_{n}^{i}}} \cdot y^{s_{n}^{i}}-\frac{1}{a^{s_{n}^{i}} b^{s_{n}^{i}}}\left(\frac{y^{s_{n}^{i}}}{a^{s_{n}^{i}}}\right)^{\frac{1-b^{s_{n}^{i}}}{b^{i}}}=0
$$

\section{Simulation Experiments}

An example of price change through a simulation scenario is shown in figure 2 . We have successfully confirmed that stable price convergence is emerged in our oligopolic virtual market at any initial price settings.

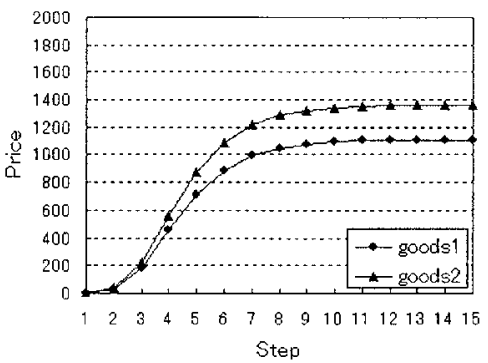

Fig. 2. Price change

\section{Summary}

We newly proposed an oligopolic virtual market approach for resource allocation problems in this paper. Firstly we explained general idea of oligopolic market model in economics. Then one of multi-agent programming, named market-oriented programming, was focused and explained its negotiation process in the oligopolic virtual market. After we defined agent behaviours, we analysed the proposed model by computer simulation experiments. Finally we applied our idea into a resource allocation problem, named utility computing service, as a case study, and finally confirmed the effectiveness of the proposed idea into general resource allocation problems. 


\title{
寡占状態を考慮した仮想市場の構築法および その資源配分問題への適用に関する研究
}

\author{
正 員 貝原 俊也* 非会員 藤井 進*
}

\author{
A Study on Modelling Methodology of Oligopolistic Virtual Market \\ and its Application into Resource Allocation Problem
}

Toshiya Kaihara*, Member, Susumu Fujii*, Non-member

\begin{abstract}
Recently, manufacturing systems have become large scale and complex. Social scientific approach is one of the promising methods to facilitate effective operation for the resource allocation problems in manufacturing systems, since the approach takes an analogy of social systems with optimality and robustness in nature. In this paper, we firstly propose a modelling methodology of oligopolistic virtual market, and develop an oligopolistic virtual market as an experimental model. Then we clarify the several important characteristics of the oligopolistic virtual market by computer simulation experiments, and try to apply the proposed method into a utility computing operational problem to validate its effectiveness into resource allocation problems.
\end{abstract}

キーワード：生産流通システム，マルチエージェント，寡占型仮想市場，均衡解，資源配分問題

Keywords: manufacturing system, multi-agent, oligopolic virtual market, equilibrium solution, resource allocation problem

\section{1. はじめに}

近年の製造環境は急速に大規模化・複雑化してきており， 従来から用いられている運用・管理手法ではその大規模化・ 複雑化に対応することが難しくなってきている。生産管理 の基本は効率的な資源配分であり，これは現在の製造業に おける基幹システムが ERP (Enterprise Resource Planning) と呼ばれていることからも分かる。そこで, 生産システム の効率的運用法を考える上では, 資源配分問題における最 適性や頑健性を有する解法の実現が重要となり，その手法 の一つとして人間社会が持つ効率性や柔軟性を抽出し利用 する社会科学的アプローチがある(1)(2)。

その社会科学的アプローチの一手法として, Wellman ら により提案された市場指向プログラミングがある ${ }^{(3)}$ 。これ は，社会科学の代表的な分野である経済学を理論的背景と するマルチエージェントプロトコルであり，新古典派経済 学の分野で証明されている完全競争市場のもつ財配分のパ レート最適性に着目して計算機上に仮想的な完全競争市場 を構築し，市場内に内包されたエージェント間のインタラ クションの結果として均衡状態を発現させ, 最終的にパレー ト最適な財の配分を導出するという手法である ${ }^{(4)(5)}$.

\footnotetext{
* 神戸大学工学部情報知能工学科

干 657-8501 神戸市灘区六甲台町

Department of Computer and Systems Engineering, Kobe University

Rokkodai, Nada, Kobe 657-8501
}

この完全競争市場では，生産者と消費者からなる市場内 の経済主体 (エージェント) は無数に存在し, かつ財の価格 は市場から与えられるという仮定が存在する ${ }^{(6)}$ 。この結果, 各エージェントの行動は, 価格を所与とするプライステイ カーとして定式化されている。しかし現実の市場では，企 業（生産者）は合併や統合を行い，意図的に寡占状態を作 り出すことで財の価格に対する影響力を大きくする（つま り，プライスメイカーになろうとする）動きが良く見られ， 実際の市場においては，このような悬占状態においても市 場の均衡状態が存在していると考えることができる。従っ て，この現実の寡占市場が有する均衡プロセスを内包した 仮想市場の構成法を明らかにすることで，従来の市場指向 プログラミングと同様, 効率性と柔軟性を併せもつ社会科 学的アプローチの一提案が可能であると考えられる。

そこで本論文では，まず，寡占市場を想定したプライス メイカーとしてのエージェントの定式化と, 生産者と消費 者間の均衡解を導くための市場裁定アルゴリズムについて 提案する。次に計算機上に寡占市場型の仮想市場（以降, 寡占型仮想市場）を構築し, 計算機実験により仮想市場に おける均衡解（クールノー解；詳細は後述）の存在につい て確認するとともに, 仮想市場の特性を評価する。最後に, 提案法の資源配分問題への適用事例としてユーティリティ コンピューティングの運用問題を取り上げ，本手法の有効 性について検討を行う。 


\section{2. 寡占市場の基本的考え方}

〈2・1〉 完全競争市場新古典派経済学において完全 競争市場とは以下の仮定を満たしている市場をいう ${ }^{(6)}$ 。

1. 同種類の財をつくる生産者の生産物は同質である。

2. 経済主体は非常に多く存在し, 個々の取引量は市場全 体での取引量に比べて十分小さい。

3. 個々の経済主体は，その行動を決定する際に他の経済 主体に与える影響を考慮しない。

4. 個々の経済主体は, 市場価格や財の特性について完全 な情報をもっている。

このような完全競争市場においてすべての財の需要量（の 総和）と供給量（の総和）が等しくなった状態を競争均衡と よぶ。このとき，完全競争市場において消費者の効用に対 してパレート最適な財の配分が得られることが知られてい る ${ }^{(6)}$ 。また，上記の 3 の仮定より完全競争市場においては 経済主体が市場における財の価格を所与のものとして利己 的に行動するという特徵がある。これをプライステイカー という。

〈2・2〉寡占市場＼cjkstart前章にて述べたように，現実の市場 には価格を所与と考えず価格に対する自身の行動による影 響を考慮する経済主体が存在する場合が多い。このような 主体をプライスメイカーと呼ぶ (6)。そこで本論文では，よ り現実的な寡占市場を構築する上で，前節に示した完全競 争市場の仮定のうち 2 と 3 の項目に変更を加え, 生産者に プライスメイカーとしての特徵を与えるものとする。

2’ 生産者は少数であり, 一生産者の行動が市場の価格に 影響を及ぼす。

3'個々の生産者は, その行動を決定する際に他の消費 者・生産者に与える影響を考慮する。

鼻占市場において，一般に生産された財は必ずすべて消費 されると仮定する。それにより，市場に存在する財の数量 と消費者の需要関数から価格が決定されるものとする。す なわち財 $i$ に対する市場全体の需要関数 $\left(D_{i}^{\text {sum }}\right)$ の逆関数 $P_{i}$ を用いて考える。市場に存在する財 $i$ の生産者すべての 生産量の総和を $y_{i}^{\text {sum }}$ とすると,

$$
p_{i}=P_{i}\left(y_{i}^{\text {sum }}\right)
$$

となり，これより, $y_{i}^{\text {sum }}$ から財 $i$ の価格 $p_{i}$ が求められる。市場 に存在する生産者の数を $N$ とし，生産者を $s_{n}(n=1, \ldots, N)$ と表すと, ある生産者 $s_{n}$ は, 他の生産者の生産量を一定と 仮定することで，価格 $p_{i}$ に対する自己の生産量 $y_{i}^{s_{n}}$ の関数 を得ることが出来る。すなわち,

$$
p_{i}=P_{i}\left(y_{i}^{s_{n}}\right)=P_{i}\left(\overline{y_{i}^{s_{1}}}+\ldots+y_{i}^{s_{n}}+\ldots+\overline{y_{i}^{s_{N}}}\right)
$$

ただし $\overline{y_{i}}$ : const, となる。ここで, 財 $i を ~ y_{i}^{s_{n}}$ 生産するの に必要な費用を費用関数 $C_{i}^{s_{n}}\left(y_{i}^{s_{n}}\right)$ を用いて表すと, 各生産 者の利潤 $\pi^{s_{n}}$ は,

$$
\pi^{s_{n}}=P_{i}\left(y_{i}^{s_{n}}\right) * y_{i}^{s_{n}}-C_{i}^{s_{n}}\left(y_{i}^{s_{n}}\right)
$$

となる。生産者はこの自己の利潤を最大とするように生産 量を決定する。この関係を関数で表したものを反応関数と いい，次のように表す。

$$
y_{i}^{s_{n}}=h\left(y_{i}^{s_{n}}\right)=h\left(\overline{y_{i}^{s_{1}}}+\ldots+y_{i}^{s_{n}}+\ldots+\overline{y_{i}^{s_{N}}}\right) \ldots \ldots
$$

ここで,すべての生産者の反応関数を満たす解 $y_{i}^{\hat{s}_{n}}=$ $\left(y_{i}^{\hat{s}_{1}}, \ldots, y_{i}^{\hat{s}_{N}}\right)$ をクールノー均衡解といい, これはそれぞれの 生産者が他の生産者の生産量を予想して自己の最適な生産 量を決定するとき, 結果として得られる生産量の組が予想 していた生産量の組と一致する点であることからナッシュ 均衡解ともなっている。簡単な例として, 財の種類が 1 , 消 費者は無数に存在し, 生産者の数が $2\left(s_{1}, s_{2}\right)$ の寡占市場を 考えると，それぞれの反応関数は，

$$
\begin{aligned}
& y_{1}^{s_{1}}=h\left(y_{1}^{s_{1}}\right)=h\left(\overline{y_{1}^{s_{1}}}+\overline{y_{1}^{s_{2}}}\right) . \\
& y_{1}^{s_{2}}=h\left(y_{1}^{s_{2}}\right)=h\left(\overline{y_{1}^{s_{1}}}+y_{1}^{s_{2}}\right) .
\end{aligned}
$$

となる。そしてこのとき収束の十分条件は，生産者が他の 生産者の生産量を所与として利潤を増加させる方向に生産 を調整することであり，この例では，反応関数の傾きから 以下のようになる。なおこの十分条件は，通常の競争原理 が働く市場において一般に成立している。

$$
\left|\frac{\partial h\left(y_{1}^{s_{2}}\right)}{\partial y_{1}^{s_{1}}}\right|<\left|\frac{\partial y_{1}^{s_{2}}}{\partial h\left(y_{1}^{s_{1}}\right)}\right| .
$$

\section{3. 仮想市場の定式化}

$\langle\mathbf{3} \cdot \mathbf{1}\rangle$ 仮想市場の基本構造 本論文では， $I$ 種類の財 と, 消費エージェント $c_{m}(m=1, \ldots, M)$, また, 財 $i$ を生産 する生産エージェント $s_{n}^{i}\left(n=1, \ldots, N_{i}\right)$ が存在する寡占市 場型の仮想市場を構築する (Fig. 1)。財の価格は，それぞ れ価格ベクトル $p=\left(p_{1}, \ldots, p_{I}\right)$ で表現する。

消費エージェントは，初期状態において保有している財 の量すなわち初期保有財のベクトル $e^{c_{m}}$ に基づく予算の範 囲内で, 自身の効用が最大となるような各財への需要関数 を提示する。生産エージェントは, 自身が生産する財に対 する市場全体の需要関数と, 他の生産エージェントの生産 量から，利潤が最大になるような生産量を提示する。この とき，自身の生産量に応じて財の価格が変化することを考 慮する (プライスメイカーの仮定)。

$\langle\mathbf{3} \cdot \mathbf{2}\rangle$ 取引決定のメカニズム 本論文で提案する寡 占型仮想市場が内包する取引解 (最終的な均衡解) 導出の 手順について以下に示す。

Step1： 各財 $(1, \ldots, i, \ldots I)$ の初期価格ベクトル $p^{i n i t}=$ $\left(p_{1}^{i n i t}, \ldots, p_{i}^{i n i t}, \ldots, p_{I}^{i n i t}\right)$, 各消費エージェント $c_{m}$ の初期 保有財 $e^{c_{m}}=\left(e_{1}^{c_{m}}, \ldots, e_{I}^{c_{m}}\right)$, 各生産エージェント $s_{n}^{i}$ の初 期生産量 $y_{i, \text { init }}^{s_{n}^{i}}$ を与える。

Step2: 消費エージェントが, 現在の財の価格ベクトル から各財に対する需要関数を提示し, 各財に対する市場 の総需要関数を求める。 


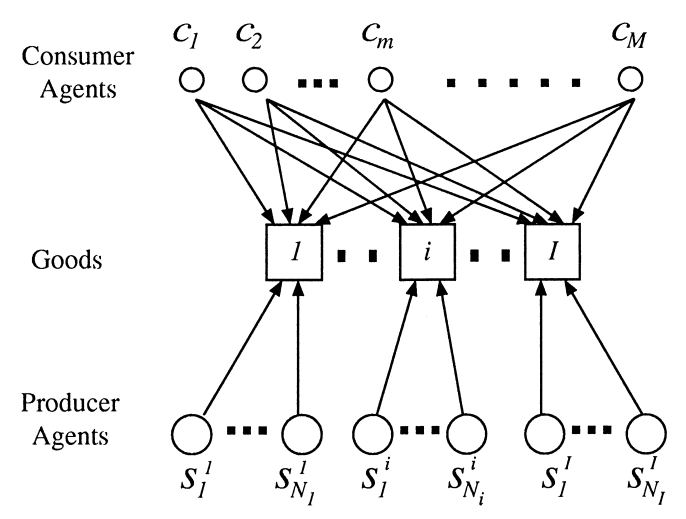

図 1 仮想市場モデル

Fig. 1. Virtual market model

Step3: 各財のクールノー均衡解を求めるため, $i=1$ に 初期設定する。

Step4: 財 $i$ を生産するすべての生産エージェント $s_{n}^{i}(n=$ $\left.1, \ldots, N_{i}\right)$ が順に自身が利潤最大となる生産量を提示する。 なお生産量の計算式はく3.4〉節にて示す。

Step5: 提示された各生産エージェントの生産量の変化 が一定以上なら Step4 へ戻る。生産量の変化が一定以下 になればクールノー均衡解 $\hat{y}_{i}^{s_{n}^{i}}\left(n=1, \ldots, N_{i}\right)$ が得られた と判断し次へ。

Step6: すべての財についてクールノー均衡解が得られ るまで， $i$ を 1 進め Step4 に戻る。すべての財について のクールノー均衡解 $\hat{y}_{i}^{i}\left(n=1, \ldots, N_{i} \mid i=1, \ldots, I\right)$ が得ら れたら次へ。

Step7: 決定された各財の生産量の総和より, 価格べク トルを更新する。価格の変化量が一定以上なら Step2 。 価格の変化量が一定以下になれば終了。

以上の手順により，まず Step5 にて各財 $i$ に対するクール ノ一均衡解 $\hat{y}_{i}^{i}\left(n=1, \ldots, N_{i} \mid i=1, \ldots, I\right)$ を求め, それにより 得られる価格 $p=\left(p_{1}, \ldots, p_{I}\right)$ を消費者に提示して消費者の 需要関数を更新し, さらにクールノー均衡解を求めることを 繰り返し最終的な均衡解 $y_{i}^{s_{n}^{i}}{ }^{\text {finish }}\left(n=1, \ldots, N_{i} \mid i=1, \ldots, I\right)$ を得る。

従来の経済学における寡占市場では，市場の購買力を一 定と仮定している ${ }^{(6)}$ 。しかし，消費者の需要は一つの財の 価格から決まるのではなく，市場に存在するすべての財の 価格により動的に決定されるものであるため，本論文では， このようにクールノー均衡解のフィードバックを行うこと で，通常の経済理論に示される均衡モデル ${ }^{(6)} に$ 比べても現 実の取引により近い状況で最終的な均衡解を求めることが 可能となる。また，このフィードバックを考慮することに より, 本論文で提案する寡占型人工市場は, 生産エージェ ントのクールノー均衡メカニズムを基本とするミクロな振 舞いと, それに対する消費エージェントを含めた市場全体 のマクロな形質とが相互にやり取りされる，いわゆるミク ロ・マクロループの構造を有するものとなっている。 $\langle\mathbf{3} \cdot \mathbf{3}\rangle \quad$ 消費エージェントの定式化

$\langle\mathbf{3} \cdot \mathbf{3} \cdot \mathbf{1}\rangle$ 効用関数 消費エージェント $c_{m}$ は消費ベク トル $x^{c_{m}}=\left(x_{1}^{c_{m}}, \ldots, x_{I}^{c_{m}}\right)$ の関数である効用関数 $u^{c_{m}}\left(x^{c_{m}}\right)$ を 最大化するように財の消費量を決定する。ここでは効用関 数として経済学で最も基本的なコブ=ダグラス型関数 ((8) 式）用いる。

$$
u^{c_{m}}=a^{c_{m}} \prod_{i=1}^{I}\left(x_{i}^{c_{m}}\right)^{c_{i}^{c_{m}}}
$$

ただ $\sum_{i=1}^{I} b_{i}^{c_{m}}=1,\left(0<a^{c_{m}}, b_{i}^{c_{m}} \quad i=1, \ldots, I\right)$

$\langle\mathbf{3} \cdot \mathbf{3} \cdot \mathbf{2}\rangle$ 需要関数 各消費エージェントは, 一定の 予算制約の下で財の購買を行う。消費エージェント $c_{m}$ の 予算 $B^{c_{m}}$ は, 初期保有財 $e^{c_{m}}$, および財の価格 $p$ により決 定され，以下のように表される。

$$
B^{c_{m}}=\sum_{i=1}^{I} p_{i} e_{i}^{c_{m}}
$$

この予算制約の中で, 効用関数を最大にするように消費量 を決定する。この関係を最適化問題の標準形にすると (10) 式のようになる。

$$
\begin{array}{ll}
\min & -a^{c_{m}} \prod_{i=1}^{I}\left(x_{i}^{c_{m}}\right)^{b_{i}^{c_{m}}} \\
\text { s.t. } & \sum_{i=1}^{I} p_{i} x_{i}^{c_{m}} \leq B^{c_{m}}
\end{array}
$$

本論文では, 消費エージェントの効用は財の消費量のみ に左右されるため消費エージェントは予算のすべてを財の 消費にあてるものとする。そこで，(10) 式の制約条件を等 式制約とし非線形計画問題を解くことで, 最終的に需要関 数は (11) 式のように求まる。

$$
x_{i}^{c_{m}}(p)=\frac{b_{i}^{c_{m}} B^{c_{m}}}{p_{i}}(i=1,2, \ldots, I)
$$

〈3・4〉生産エージェントの定式化 本論文では生産 エージェント $s_{n}^{i}$ の行動は〈2・2〉節に示したプライステイ カーの仮定に従うものとする。すなわち, 財 $i$ の市場全体で の逆需要関数を考え, 他の生産エージェントの生産量を一 定と仮定して自己の利潤を最大とするように生産量を決定 し，他の生産エージェントに対して提示する。ここで，生 産エージェントの生産関数は以下のように定式化する。

$$
y^{s_{n}^{i}}=a^{s_{n}^{i}}\left(x^{s_{n}^{i}}\right)^{b^{s_{n}^{i}}} \quad\left(0<a^{s_{n}^{i}}, 0<b^{s_{n}^{i}}<1\right)
$$

この形は生産に必要な資源が増えるにつれて生産性が低下 する収穫派減の性質を表したものであり，これは初期投資 が必要となる産業, すなわち一般に資源集約型と呼ばれる 産業に見られる特徴である。またこのような産業ほど寡占 市場になる場合が多く, 実問題に適用することを考えた場 合，この仮定は妥当であると考えられる。

本モデルでは，生産者は資金から財を生産するとする。 よって利潤は 


$$
\pi^{s_{n}^{i}}=p_{i} y^{s_{n}^{i}}-x^{s_{n}^{i}}
$$

で得られる。ここで財 $i$ の価格は所与ではなく生産量によ り変化することを考慮するので，(13) 式は

$$
\pi^{s_{n}^{i}}=P_{i}\left(y^{s_{n}^{i}}\right) \cdot y^{s_{n}^{i}}-x^{s_{n}^{i}}
$$

となり，この利潤が最大になる生産量は以下の最大化問題 を解くことで求められる。

$$
\begin{array}{ll}
\max & P_{i}\left(y^{s_{n}^{i}}\right) \cdot y^{s_{n}^{i}}-x^{s_{n}^{i}} \\
\text { s.t. } & y^{s_{n}^{i}} \leq a^{s_{n}^{i}}\left(x^{s_{n}^{s_{n}}} b^{b_{n}^{s_{n}}}\right.
\end{array}
$$

本論文では，生産エージェントはインプットする資金に 対して生産可能な最大の生産量を必ず生産すると仮定する ため，(15) 式の制約条件を等式制約としてこの非線形計画 問題を解くことで利潤最大となるような $y^{s_{n}^{i}}$ は,

$$
P\left(y^{s_{n}^{i}}\right)+\frac{\partial P\left(y^{s_{n}^{i}}\right)}{\partial y^{s_{n}^{i}}} \cdot y^{s_{n}^{i}}-\frac{1}{a^{s_{n}^{i}} b^{s_{n}}}\left(\frac{y^{s_{n}^{i}}}{a^{s_{n}^{i}}}\right)^{\frac{1-b^{s_{n}}}{b^{s_{n}}}}=0
$$

を満たすものとして求められる。ここで左辺第 3 項は，生 産関数の逆関数である費用関数の一階微分となるので, 費用 関数を $C^{s_{n}^{i}}\left(y^{s_{n}^{i}}\right)$ として表すと (16) 式は以下のようになる。

$$
P\left(y^{s_{n}^{i}}\right)+\frac{\partial P\left(y^{s_{n}^{i}}\right)}{\partial y^{s_{n}^{i}}} \cdot y^{s_{n}^{i}}-\frac{\partial C^{s_{n}^{i}}\left(y^{s_{n}^{i}}\right)}{\partial y^{s_{n}^{i}}}=0 .
$$

各生産エージェントが，(4) 式に示した反応関数に対して ここで得られる $y^{s_{n}^{i}}$ を順次決定していくことで，〈3·2〉節

の Step3 $\sim$ Step5 に示した手順に従い，クールノー解が求 まる。なお Step4 の生産量は，(17) 式の解として求まる。

\section{4. 特性解析実験}

本章では，これまでの定式化に基づき富占市場型の仮想 市場を計算機上に構築し，均衡解への収束過程を確認する とともに仮想市場の特性を評価する。なお今回は，提案手 法の基本特性を確認するために，最も基本的な二財モデル にて特性解析を行う。

まず，始めに価格の収束性を確認するための基本特性解 析を行なった後，市場に存在する消費エージェントの均質 性と生産エージェントの大数量効果について確認する。な 抗これらの特性は，提案手法を実問題へ適用する際，重要 な指針となる。

〈4・1 基本特性解析 まず，本実験における基本パ ラメータを Table 1 に示す。な抗ここでは，均衡解へ収束 過程をみるため，消費エージェントと生産エージェントが それぞれ均質な状況を想定している。またこれらの設定は， (7) 式に示した収束の十分条件を満足している。

ここで消費エージェントの効用関数は，指数部の值が大 きいほどその財への選好が高いことを意味する。この実験 条件では, すべての消費エージェントは財 2 をり好むもの としている。この条件のもとで, 各財の初期価格 $\left(p_{1}^{\text {init }}, p_{2}^{\text {init }}\right)$
表 1 実験パラメータ

Table 1. Experimental parameters.

\begin{tabular}{c|l|l}
\hline \multicolumn{1}{c|}{ Comsumer Agent } & Producer Agent & Goods \\
\hline \hline$M=10$ & $N_{1}=2$ & $I=2$ \\
& $N_{2}=2$ & \\
\hline$u^{c_{m}}=x_{1}^{c_{m} 0.4} x_{2}^{c_{m} 0.6}$ & $y^{s_{n}^{l}}=\left(x_{n}^{s_{n}}\right)^{0.5}$ & \\
$\left(e_{1}^{c_{m}}, e_{2}^{c_{m}}\right)=(50,50)$ & $(i=1,2 \mid n=1,2)$ & \\
$(m=1, \ldots, M)$ & & \\
\hline
\end{tabular}

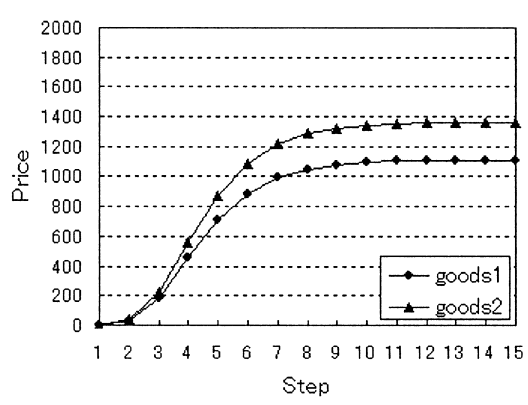

(a) $\left(p_{1}^{\text {init }}, p_{2}^{\text {init }}\right)=(1,1)$

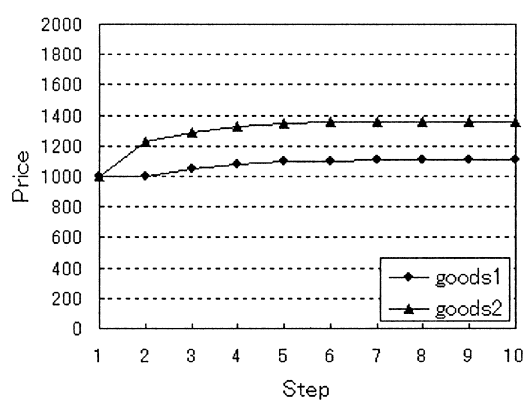

(b) $\left(p_{1}^{\text {init }}, p_{2}^{\text {init }}\right)=(1000,1000)$

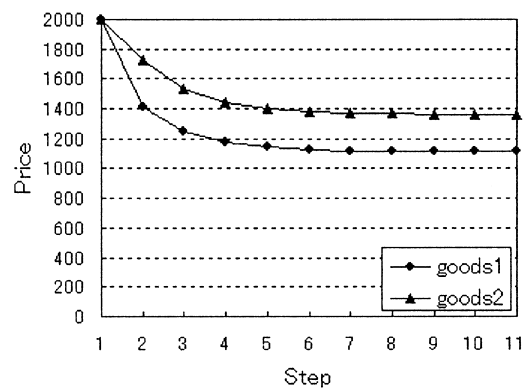

(c) $\left(p_{1}^{\text {init }}, p_{2}^{\text {init }}\right)=(2000,2000)$

図 2 初期価格の違いによる収束状況比較

Fig. 2. Initial price comparison.

をそれぞれ $(1,1),(1000,1000),(2000,2000)$ とした場合の 均衡状態への価格推移を Fig.2 に示す。

クールノー均衡解から新たに価格を求めフィードバック するサイクル（〈3·2〉節における Step2～Step6）を 1 ス テップとして横軸に表している。すなわち各々の点がクー ルノ一均衡点に扔ける価格となっている。これらの結果よ り, 提案する仮想市場に扔いて, 生産エージェントと消費 エージェントの交渉の結果, 安定した均衡状態が発現する こと，および取引における財の初期価格が最終的な均衡価 格，均衡取引量には影響を及ぼさないことがわかる。つま り本手法では, 最終的な均衡解のみに着目するならば財の 
初期価格は任意に決定しても良いことが明らかとなった。 ただしステップ数を比較すると, 最終的な均衡価格に最も 近い $\left(p_{1}^{\text {init }}, p_{2}^{\text {init }}\right)=(1000,1000)$ が早い段階で均衡状態に収 束していることから，経験的に均衡価格の範囲が推定でき るのならばその範囲の価格を初期価格とすることで均衡解 を獲得するまでの計算時間を短縮することが可能となる。 また，財 2 の方が価格が高く生産量も多くなっているのは 本実験条件では消費エージェントが財 2 の方をより好むた めであり，本結果は理論的な傾向と合致する。

$\langle\mathbf{4} \cdot \mathbf{2}\rangle$ 消費エージェントの均質性 一般に, 市場に おける消費者の効用は多様であるため，ここでは市場に存 在する消費エージェントの特性が不均質な場合における均 衡解について考察する。

消費エージェント数は 10 とし，各消費エージェントの

\section{表 2 実験パラメータ（消費者）}

Table 2. Experimental parameters (consumers).

\begin{tabular}{|c|c|c|}
\hline & $u^{c_{m}}$ & $\left(e_{1}^{c_{m}}, e_{2}^{c_{m}}\right)$ \\
\hline$c_{1}$ & $x_{2}^{c_{1}}$ & $(50,50)$ \\
\hline$c_{2}$ & $x_{1}^{c_{2} 1.6}$ & $(50,50)$ \\
\hline$c_{3}$ & $x_{1}^{c_{3} 0.2} x_{2}^{c_{3} 0.8}$ & $(30,70)$ \\
\hline$c_{4}$ & $x_{1}^{c_{4} 0.2} x_{2}^{c_{4} 0.8}$ & $(50,50)$ \\
\hline$c_{5}$ & $x_{1}^{c_{5} 5^{0.2}} x_{2}^{c_{5}}$ & $(70,30)$ \\
\hline$c_{6}$ & $x_{1}^{c_{6} 6^{0.8}} x_{2}^{c_{6} 6^{0.2}}$ & $(30,70)$ \\
\hline$c_{7}$ & $x_{1}^{c_{7}^{0.8}} x_{2}^{c_{7}^{0.2}}$ & $(50,50)$ \\
\hline$c_{8}$ & $x_{1}^{c_{8}^{0.8}} x_{2}^{c_{8} 0^{0.2}}$ & $(70,30)$ \\
\hline$c_{9}$ & $x_{1}^{c_{9} 0.2} x_{2}^{c_{9} 0.8}$ & $(50,50)$ \\
\hline$c_{10}$ & $x_{1}^{c_{10} 0^{0.2}} x_{2}^{c_{10}} c^{0.8}$ & $(50,50)$ \\
\hline
\end{tabular}

表 3 実験パラメー夕（生産者と財）

Table 3. Experimental parameters (producers \& goods).

\begin{tabular}{l|l}
\hline Producer Agent & Goods \\
\hline \hline$N_{1}=2$ & $I=2$ \\
$N_{2}=2$ & \\
\hline$y^{s_{n}^{l}}=\left(x^{s_{n}^{l}}\right)^{0.5}$ & $\left(p_{1}^{\text {init }}, p_{2}^{\text {init }}\right)=(100,100)$ \\
$(i=1,2 \mid n=1,2)$ & \\
\hline
\end{tabular}

表 4 均衡解

Table 4. Equilibrim solutions.

\begin{tabular}{|c|c|}
\hline$\left(p_{1}, p_{2}\right)$ & $\left(y_{1}^{\text {sum }}, y_{2}^{\text {sum }}\right)$ \\
\hline \hline$(1168.4,1318.3)$ & $(467.04,526.94)$ \\
\hline
\end{tabular}

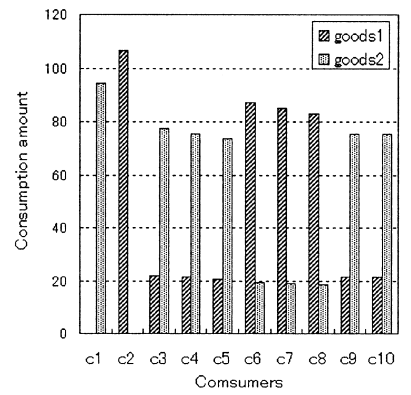

(a)

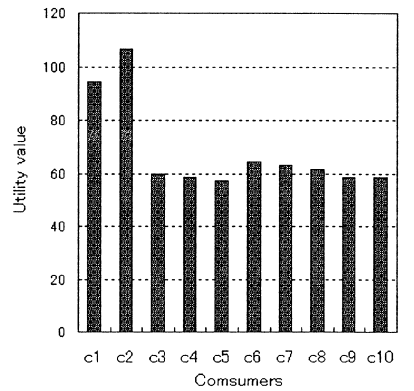

(b)
困 3 消費者の消費量と効用

Fig. 3. Consumption and utility of consumers.
パラメータを Table 2 のように設定した。 $c_{1}, c_{2}$ は一方の 財のみを選好する消費エージェントである。財の選好を不 均質とするために，この市場全体では財 2 を選好する消費 エージェントが多くなるようにしている。その他, 生産エー ジェントのパラメータおよび財の初期価格は Table 3 のよ うに設定した。これはく4・1〉節と同じ状況となっている。

均衡状態での各財の価格および総生産量を Table 4 に, 各 消費エージェントの消費量と効用を Fig. 3(a), (b) にそれぞ れ示す。まず $c_{1}$ と $c_{2}$ について, 財の消費量の総和は他の 消費エージェントと大きな差はないにも関わらず効用が非 常に大きくなっている。これは, 購入の対象を 1 つの財に 固定することによって効用関数が収穫一定となるからであ る。このように，購入対象の財の種類を絞り込むことで消 費エージェントの効用を上昇させることが可能となること が分かった。この傾向は, 効用関数のべき乗係数や市場に 存在する財の種類とも深く関与し, 実問題において資源配 分をコントロールする際の重要な指針となる。さらに提案 する寡占市場では, 効用が 1 つの財に偏っている消費エー ジェントが存在しても均衡解が得られており, 適用可能な 実問題の範囲は広いと考えられる。

次に, $c_{3} \sim c_{5}$ の中では $c_{3}$ がもっとも効用が高く, $c_{6} \sim c_{8}$ の中では $c_{6}$ が最も効用が高い。これは, 均衡状態での価格 が高い財 2 を初期状態でより多く持っているため予算が相 対的に多くなるからである。 $c_{3}$ と $c_{6}$ の選好を表す指数を 考えると, 初期状態においてそのエージェントが好む財を 多く持っているからといって効用が上がるわけではないこ とが明らかになった。これも実問題の定式化の際に考慮に いれるべき点である。

〈4·3〉 生産エージェントの大数量効果 ここでは生 産エージェントの数の变化が消費者の効用值へ与える影響 を調べる。ある財を生産する生産エージェントの数が多く なることは市場の寡占度合いが低くなり，自身の行動の価 格に対するプライスメイカーとしての影響が相対的に小さ くなることを意味する。

財の数が 2 の市場において, 財 1 , 財 2 それぞれの生産 エージェントの数を変化させて実験を行う。各パラメータ は Table 5 のように設定する。財 1 を生産する生産エージェ ントの数を $k$, 財 2 を生産する生産エージェントの数を $l$ と 表し，それぞれ $1, \ldots, 10$ と変化させる。

$k, l$ の值に対する均衡状態での各消費エージェントの効 用を Table 6 に示す。まず，一方の財の生産エージェント数 のみが増加していった場合を考える。 $k=2$ の行と $l=2$ の

\section{表 5 実験パラメータ}

Table 5. Experimental parameters.

\begin{tabular}{l|l|l}
\hline Comsumer Agent & Producer Agent & Goods \\
\hline \hline$M=10$ & $N_{1}=k$ & $I=2$ \\
& $N_{2}=l$ & \\
\hline$u^{c_{m}}=x_{1}^{c_{m} 0.4} x_{2}^{c_{m} 0.6}$ & $y^{s_{n}^{l}}=\left(x^{s_{n}}\right)^{0.5}$ & $\left(p_{1}^{\text {init }}, p_{2}^{\text {init }}\right)=$ \\
$\left(e_{1}^{c_{m}}, e_{2}^{c_{m}}\right)=(50,50)$ & $(i=1,2 \mid n=$ & $(100,100)$ \\
$(m=1, \ldots, M)$ & $1, \ldots, k, 1, \ldots, l)$ & \\
\hline
\end{tabular}


表 6 効用值の変化

Table 6. Matrix of utility value.

\begin{tabular}{|c|c|c|c|c|c|}
\hline$k \backslash l$ & 2 & 3 & 4 & 5 & 6 \\
\hline 2 & $\mathbf{5 0 . 2 3}$ & $\mathbf{5 1 . 6 8}$ & $\mathbf{5 4 . 2 0}$ & $\mathbf{5 5 . 4 9}$ & $\mathbf{5 6 . 7 1}$ \\
\hline 3 & $\mathbf{5 0 . 0 8}$ & $\mathbf{5 0 . 2 5}$ & 51.50 & 52.28 & 53.04 \\
\hline 4 & $\mathbf{5 0 . 9 5}$ & 50.04 & $\mathbf{5 0 . 2 5}$ & 50.61 & 51.02 \\
\hline 5 & $\mathbf{5 1 . 5 4}$ & 50.23 & 50.05 & $\mathbf{5 0 . 2 5}$ & 50.53 \\
\hline 6 & $\mathbf{5 2 . 1 3}$ & 50.49 & 50.00 & 50.08 & $\mathbf{5 0 . 2 5}$ \\
\hline 7 & $\mathbf{5 2 . 7 0}$ & 50.78 & 50.03 & 50.01 & 50.10 \\
\hline 8 & $\mathbf{5 3 . 2 5}$ & 51.09 & 50.12 & 50.01 & 50.02 \\
\hline 9 & $\mathbf{5 3 . 7 7}$ & 51.40 & 50.24 & 50.05 & 50.00 \\
\hline 10 & $\mathbf{5 4 . 2 6}$ & 51.78 & 50.38 & 50.12 & 50.02 \\
\hline \multicolumn{2}{|c|}{$k \backslash l$} & 7 & 8 & 9 & 10 \\
\hline 2 & $\mathbf{5 7 . 8 5}$ & $\mathbf{5 8 . 9 0}$ & $\mathbf{5 9 . 8 8}$ & $\mathbf{6 0 . 8 5}$ \\
\hline 3 & 53.78 & 54.50 & 55.18 & 55.85 \\
\hline 4 & 51.45 & 51.88 & 52.32 & 52.75 \\
\hline 5 & 50.85 & 51.19 & 51.53 & 51.88 \\
\hline 6 & 50.48 & 50.74 & 51.02 & 51.30 \\
\hline 7 & $\mathbf{5 0 . 2 5}$ & 50.45 & 50.67 & 50.90 \\
\hline 8 & 50.11 & $\mathbf{5 0 . 2 5}$ & 50.42 & 50.61 \\
\hline 9 & 50.04 & 50.13 & $\mathbf{5 0 . 2 5}$ & 50.40 \\
\hline 10 & 50.00 & 50.05 & 50.14 & $\mathbf{5 0 . 2 5}$ \\
\hline
\end{tabular}

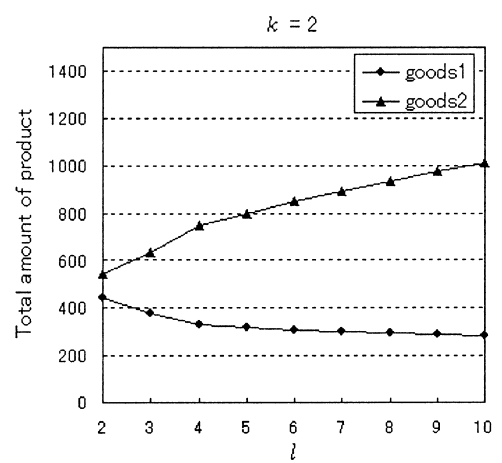

図 4 生産量の変化

Fig. 4. Total amount of products.

列のそれぞれの変化を見ると，共に消費者の効用が上がっ ていることがわかる。これは，頞占度合いが下がるほうの 財の生産量が大幅に増加するからである。この結果として, $k=2$ における各財の総生産量の変化を Fig. 4 に示す。

次に, Table 6 に扔いて財 1 , 財 2 の生産エージェント数 を共に増加させていった場合を考える。生産エージェント 数が増加しても効用が上がらないのは, 生産量が増加して いないためである。生産エージェント数が財 1 , 財 2 とも 増加しているにもかかわらず生産量が一定となるのは，消 費者の予算は財の価格に対して線形であるため，すべての 財の価格が下がるとき，それに比例して予算も下がり財の 需要量が変化しないからである。

\section{5. ケーススタディ}

ここでは, 本研究で提案している葟占市場を模した仮想市 場について人工システムの運用問題への適用例を示す。本 システムは, コンピュータのプロセッサを想定したリソース とリソースの処理能力を提供するリソースサプライヤ $(\mathrm{RS})$,
リソースでの処理を要求するユーザからなる。 RS はリソー スの能力をマーケットに提供し，ユーザがそれを購入する ようなユーティリティコンピューティングサービスを想定 したモデルであり(7)，ここではある一定期間におけるリソー スの均衡配分を考える。

このモデルにおいてユーザ数 5 , リソース数 2 ，リソース 1 を提供する $\mathrm{RS}$ 数 2 , リソース 2 を提供する $\mathrm{RS}$ 数 3 , と して実験を行う。ここで, money $^{j}$ : ユーザ $j$ がコンピュー ティングサービスに払う金額, $t i m e_{r}^{j}:$ リソース $r$ がユーザ $j$ の処理を 1 単位処理するのにかかる平均時間, $Q_{r}^{j}$ : ユー ザ $j$ のリソース $r$ の処理能力の消費量, $y_{r}^{s}:$ リソース $r$ を 提供する $\mathrm{RS} s$ の処理能力，とする。

$\langle\mathbf{5} \cdot \mathbf{1}\rangle$ ユーザの定式化 ユーザの効用関数は (8) 式に 従い次のように定式化できる。

$$
u^{j}=a^{j}\left(Q_{1}^{j}\right)^{b_{1}^{j}}\left(Q_{2}^{j}\right)^{b_{2}^{j}} \quad\left(0<a^{j}, b_{r}^{j} \quad r=1,2\right)
$$

ここで選好を表す指数 $b_{r}^{j}$ は以下のようにする。

$$
b_{1}^{j}: b_{2}^{j}=\frac{1}{t i m e_{1}^{j}}: \frac{1}{t i m e_{2}^{j}} \quad \text { ただし } b_{1}^{j}+b_{2}^{j}=1
$$

これにより，処理能力が速いリソースでの処理をより好む

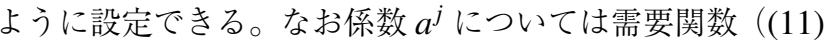
式）に現れないのでここでは簡便的に $a^{j}=1$ とする。 次にユーザの初期保有財量は以下の式で決定する。

$$
e_{r}^{j}=\text { money }^{j} \cdot \frac{1 / \text { time }_{r}^{j}}{\sum_{r} 1 / \text { time }_{r}^{j}}
$$

このように定式化することにより，多額の money $^{j}$ を払う ユーザほど予算が大きくなり，均衡状態での処理能力の配 分が大きくなる。加えて, 処理能力が速いリソースの処理 能力をより多く初期保有するように設定できる。

$\langle\mathbf{5} \cdot \mathbf{2}\rangle \quad$ リソースサプライヤ $(\mathbf{R S})$ の定式化 生産関数 は以下のような収穫派減型のものを用いる。

$$
y_{r}^{s}=a_{r}^{s}\left(x_{r}^{s}\right)^{b_{r}^{s}} \quad\left(0<a_{r}^{s}, 0<b_{r}^{s}<1\right)
$$

この設定は，例えば一般の企業が処理能力を増加させるこ とを想定した場合，新たにマシンやサーバルームが必要に なることや，八イエンドマシンになればなるほど処理能力 あたりの単価が増加することに該当する。

各ユーザのパラメータを Table 7 に示す。ここでは，リ ソース 1 を浮動小数演算プロセッサ, リソース 2 を整数演 算プロセッサとし，ユーザ $1 ， 2$ は整数演算が比較的多い ユーザ，ユーザ 3,4 は浮動小数点演算が多いユーザ，ユー ザ 5 は特に特徵のないユーザと想定する。

$\langle\mathbf{5} \cdot \mathbf{3}\rangle$ 特性解析 上述の設定を用いてシミュレーショ ン実験を行った。まず均衡状態での各ユーザへの処理能力 の配分と各ユーザの初期状態における効用 $u_{0}^{j}$, 均衡状態で 
表 7 設定パラメータ

Table 7. Parameter settings.

\begin{tabular}{|c|c|c|c|c|c|}
\hline & user1 & user2 & user3 & user4 & user5 \\
\hline time $_{1}^{j}$ & 4 & 4 & 3 & 3 & 5 \\
\hline time $_{2}^{j}$ & 6 & 6 & 12 & 12 & 5 \\
\hline money $^{j}$ & 200 & 50 & 150 & 80 & 100 \\
\hline
\end{tabular}

表 8 処理能力と効用值

Table 8. Processing power and utility value.

\begin{tabular}{|c|c|c|c|c|c|}
\hline & user1 & user2 & user3 & user4 & user5 \\
\hline$Q_{1}^{j}$ & 88.89 & 22.10 & 104.2 & 55.57 & 33.54 \\
\hline$Q_{2}^{j}$ & 172.60 & 43.15 & 76.30 & 40.70 & 98.23 \\
\hline$u_{0}^{j}$ & 102.03 & 25.51 & 90.94 & 48.50 & 50.00 \\
\hline$u^{j}$ & 115.52 & 28.89 & 97.90 & 52.21 & 57.40 \\
\hline
\end{tabular}

表 9 RS の利潤

Table 9. Profit of RS.

\begin{tabular}{|c|c|c|c|c|c|}
\hline & \multicolumn{2}{|c|}{ Resouce1 } & \multicolumn{3}{c|}{ Resouce 2 } \\
\hline & RS 1 & RS 2 & RS 3 & RS 4 & RS 5 \\
\hline Profit & 56767 & 66376 & 20249 & 21280 & 21945 \\
\hline
\end{tabular}

の効用 $u^{j}$ を Table 8 に示す。すべてのユーザの効用が初期 状態に対して増加していることがわかる。そして均衡状態

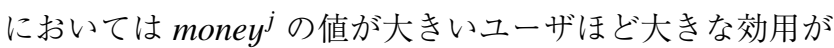
得られている。また，均衡状態での各 RS の利潤を Table 9 に示す。以上の結果より，本事例において，ユーザの効用 と RS の利潤についてナッシュニクールノー均衡解に従う効 率的なリソースの配分ができていることが分かる。

マルチエージェントシステムを用いた市場指向プログラ ミングは, その柔軟性や拡張性から QoS やスケジューリン グ問題, 電力市場への応用が期待されており, さまざまな研 究が行われている ${ }^{(8)(9)}$ 。しかしこれらの従来研究では, 市場 を構成するエージェントはあくまでプライステイカーであ るという強い制約があり，その結果，適用可能な資源配分 問題が限定的となっていた。それに対し本論文では，より 一般的なプライスメイカーにより構成される寡占市場を模 した仮想市場を構築することで，広範囲の資源配分問題に 対する合理的な解法を提案することができたと考えている。

\section{6. おわりに}

本論文では，まず寡占市場を構成するエージェントの定 式化，および提案する市場裁定アルゴリズムについて説明 した。次に計算機上に提案する夏占型仮想市場を構築し, シミュレーション実験により仮想市場における均衡解の存 在について確認するとともに，仮想市場の諸特性を明らか にした。最後に，寡占市場型仮想市場の資源配分問題への 適用事例としてユーティリティコンピューティングの運用 問題を取り上げ，提案法の実問題への適用可能性について 示した。なお今後の課題として，各エージェントや財が参 入・撤退する動的市場や，シュタッケルベルグ均衡などの より複雑な寡占状態へと拡張することなどが挙げられる。 (平成 17 年 11 月 21 日受付, 平成 18 年 1 月 31 日再受付)

\section{文献}

(1) N. Gilbert, et al.: Simulation for the Social Scientist, Open University Press (1999) (in Japanese)

ギルバート, 他 :「社会シミュレーションの技法」, 日本評論社 (2003)

(2) T. Kaihara and S. Fujii: "A study on intelligent artificial systems with adaptive behaviour", Proc. 47th annual meetings of ISCIE, pp.405-406 (2003) (in Japanese)

貝原俊也・藤井 進 :「環境適応型人工システムの構築〜社会科学 的アプローチ」, 第 47 回システム制御情報学会研究発表講演論文集, pp.405-406 (2003)

(3) M.P. Wellman: "A market-oriented programming environment and its application to destributed multicommodity flow problems", Journal of Artificial Intelligence Research, Vol.1, pp.1-23 (1993)

(4) T. Kaihara, S. Fujii, and N. Yoshimura: "Validation on Pareto optimality of Walrasian virtual market", Trans. of the Institute of Syst., Control abd Information Engineers, Vol.17, No.10, pp.444-450 (2004) (in Japanese) 貝原俊也・藤井 進・吉村徳泰 :「ワルラス型仮想市場の均衡解に 対するパレート最適性の検証」, システム制御情報学会論文集, 17, 10, pp.444-450 (2004)

(5) K. Shimada, T. Miyamoto, and S. Kumagai: "A supply chain model using market-oriented programming in consideration of inventory cost and duetime negotiation", Proc. of SICE SSI2003, pp.371-376 (2003) (in Japanese) 嶋田清孝・宮本俊幸・熊谷貞俊：「在庫費用と納期交渉を考慮した 市場指向プログラミングを用いたサプライチェインモデル」, システ ム・情報部門学術講演論文集, pp.371-376 (2003)

(6) J.B. Shoven and J. Whalley: Applying general equilibrium, Cambridge University Press (1992)

(7) R. Ernemann: "Economic scheduling in grid computing", Lecture notes in computer science, Vol.2537, pp.128-152 (2002)

(8) J.K. MacKie-Mason, et al.: "Evaluating and selecting digital payment mechanism, Interconnection and the Internet", LawrenceErlbaum, pp.113-134 (1997)

(9) H. Yamaki, M.P. Wellman, and T. Ishida: "Controlling application QoS based on a market model", Trans. of the Institute of Electronics, Information and Commun. Engineers, Vol.J81-D-I, No.5, pp.540-547 (1998)

貝 原 俊 也 (正員) 1985 年 3 月京都大学大学院工学研究科

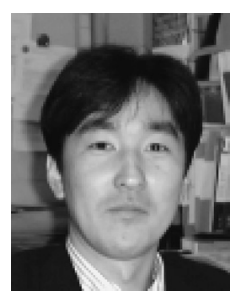
修士課程修了。三菱電機（株), 神戸大学大学院 助教授などをへて 2004 年 12 月より神戸大学工学 部教授。マルチエージェントシステムの理論と, その生産・流通・社会システムなどへの応用に関 する研究に従事。Ph.D. 日本機械学会, 日本才ぺ レーションズリサーチ学会, 精密工学会, システ ム制御情報学会，SICE，IFIP，IEEE などの会員。

藤 井進 (非会員) 1970 年 8 月ウイスコンシン大学大学

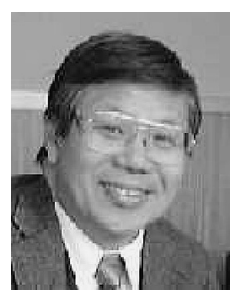
院理工学研究科機械工学専攻博士課程修了。同年 10 月神戸大学工学部助手, 1971 年 11 月神戸大 学工学部助教授, 1984 年 3 月教授になり現在に 至る。生産システム工学, オペレーションズ・リ サーチの研究に従事。Ph.D. 日本機械学会, 日本 OR 学会, 精密工学会, 情報処理学会, INFORMS, IFIP，SCS などの会員。 